\title{
POGLEDI MENTORJEV IN ŠTUDENTOV ZDRAVSTVENE NEGE NA PRAKTIČNO USPOSABLJANJE
}

\section{POVZETEK}

Prispevek obravnava mentorstvo na praktičnem usposabljanju kot obliko učenja in pomoč študentom pri opredmetenju na fakulteti pridobljenega znanja in njegovega preverjanja v praksi. Predstavljeno je usposabljanje študentov zdravstvene nege v kliničnem okolju kot obvezni del študijskega programa. Vsebinsko in časovno opredeljen program usposabljanja je pod mentorjevim vodenjem izpeljan v izbranem učnem zavodu. V enem od njih je bila opravljena raziskava, ki odkriva razlike v pogledih mentorjev in študentov na vsebino usposabljanja v kliničnem okolju, pa tudi njihova pričakovanja pri delu v praksi. Del rezultatov je predstavljen $v$ prispevku.

Ključne besede: mentor, mentorski odnos, usposabljanje študentov, pričakovanja mentorjev in študentov

\section{MENTORS' AND STUDENTS' VIEWS OF PRACTICAL TRAINING IN NURS- ING CARE - ABSTRACT}

The article examines mentorship in the context of practical training, which represents a form of education, while helping students to implement the acquired knowledge and verify it in practice. Practical training of the nursing students in clinical environment represents an obligatory part of the study programme. The programme is determined by content and duration, and is carried out under mentor's guidance. The research carried out at one of the selected institutions revealed differences between mentors' and students' perceptions of the content of training in clinical environment as well as in their expectations regarding practical work. The article presents some of the gathered results.

Keywords: mentor, mentorship, training of students, expectations of mentors and students

Dr. Nataša Kermavnar, Univerzitetni klinični center Ljubljana,natasa.kermavnar@kclj.si

Izr. prof. dr. Monika Govekar-Okoliš, Filozofska fakulteta Univerze v Ljubljani,

monika.govekar-okolis@guest.arnes.si 


\section{UVOD}

Mentorstvo v praktičnem usposabljanju je ena od oblik mentorstva, ki se pojavlja v času študija $\mathrm{z}$ namenom vodenja in usmerjanja študenta pri nadgradnji pridobljenega znanja v praksi. Študenti na praktičnem usposabljanju uporabijo na fakulteti pridobljena znanja in jih obenem preverjajo v bodočem poklicnem okolju. Pod mentorjevim vodenjem razvijajo svoje spretnosti in potenciale v okolju prakse in pridobivajo tiste veščine, ki jih potrebujejo za samostojno in suvereno delo na poklicni poti, na katero se pripravljajo. Gre za pomemben del izobraževanja posameznika tudi v luči kasnejšega iskanja zaposlitve in odpiranja zaposlitvenih možnosti.

\section{PRAKTIČNO USPOSABLJANJE ŠTUDENTOV}

Prenova študijskih programov z bolonjsko reformo je posledica sprememb in dimenzij na trgu dela, praktično usposabljanje pa z njo postaja obvezen del študijskih programov na vseh nivojih. Cilj prenovljenih programov je pridobivanje strokovnih kompetenc, ki pripomorejo k večji zaposljivosti in mobilnosti diplomantov (Govekar-Okoliš, 2013). Praktično usposabljanje ima svoje pravne podlage v Zakonu o visokem šolstvu (2006), ki med drugim določa, da je praktično usposabljanje obvezen sestavni del študijskih programov na vseh stopnjah, njegovo vrednotenje pa urejajo Merila za akreditacijo visokošolskih zavodov in študijskih programov (2004) in Merila za kreditno vrednotenje študijskih programov po ECTS (2004).

Prenovljeni študijski programi zagotavljajo razvoj kompetenc skozi novo izobraževalno paradigmo, ki v središče izobraževanja postavlja študenta in uvaja aktivne oblike študijskega dela. Takšna oblika je tudi praktično usposabljanje, ki študentu omogoča preverjanje uporabnosti teoretičnega in aplikativnega znanja, pridobljenega na fakulteti, v bodočem poklicnem okolju. Ob tem študent razvija vrsto instrumentalnih kompetenc, kot so organiziranje delovnega časa, reševanje realnih problemov, uporaba znanja v praksi, razvija pa tudi medosebne kompetence, kot so kritičnost, komunikacija, sodelovanje v timu ipd. Kompetence, ki jih študenti razvijejo med praktičnim usposabljanjem, in konkretni rezultati so vključeni v učne načrte posameznih študijskih programov (Kristl idr., 2007), za njihovo doseganje pa je smotrno upoštevati načelo razvojnosti in načelo komplementarnosti. Prvo se nanaša na študenta, na njegovo predhodno znanje, stopnjo motivacije in način razmišljanja; drugo pa je povezano z delovno organizacijo, kjer poteka praktično usposabljanje (prav tam).

Kakovostno izvajanje praktičnega usposabljanja je odgovornost in rezultat sodelovanja fakultete z načrtovanim študijskim programom in delovne organizacije, ki omogoča izvajanje usposabljanja študentov. Nenadomestljiv delež na strani delovne organizacije prispevajo izobraženi mentorji. Področje izobraževanja mentorjev je tisto, ki ponuja veliko možnosti za razvijanje dobrih diplomantov, ki bodo v prihodnosti kos izzivom na delovnem mestu. Govekar-Okoliš in Gruden (2011) poudarjata na eni strani potrebo po strokovno usposobljenem in izobraženem kadru in na drugi strani potrebo po študentih, opremljenih z znanjem, sposobnostjo in motivacijo, pa tudi zmožnostjo povezovanja teoretičnih znanj 
s praktičnimi. Pri tem sodelovalnem odnosu je pomembno, da potencialni delodajalci v usposabljanju študentov ne vidijo zgolj motnjo delovnega procesa, ampak prepoznajo tudi priložnost zase, npr. v odkrivanju in zaposlovanju mladih talentov. Praktično usposabljanje naj torej spodbuja tekmovalnost med študenti in obenem, kot je predvideno $\mathrm{V}$ Smernicah za praktično usposabljanje na Univerzi v Ljubljani (Kristl idr., 2007), ponuja možnost izmenjave študentov prek programa Erasmus.

\section{MENTORSTVO NA PRAKTIČNEM USPOSABLJANJU}

Praktično usposabljanje študenti potrebujejo zato, da se konkretno seznanijo s svojim bodočim strokovnim delom ter ob tem ovrednotijo svoja teoretična znanja s praktičnimi izkušnjami. Zato je potrebno, da fakulteta in delovna organizacija, kjer poteka praksa, zagotovita, da je usposabljanje izpeljano kakovostno (Govekar-Okoliš, 2012). Fakulteta kakovost programa zagotavlja s svojim učnim načrtom, urniki in samo organizacijo razporejanja študentov na prakso. V delovnem okolju pa je za kakovost praktičnega usposabljanja bistvenega pomena, da študenta vodi strokovno usposobljena in izkušena oseba, to je mentor.

Gre za vnaprej načrtovan proces usposabljanja in učenja v praksi z določenim programom in predvidenimi cilji, ki naj jih doseže študent. Cilji so oblikovani tako, da se lahko preverjajo sprotno ob samem izvajanju programa ali pa tudi ob njegovem zaključku. Mentor je pri tem vključen $\mathrm{v}$ proces $\mathrm{z}$ namenom, da mentoriranec sledi njegovi praksi in postaja učinkovitejši v lastnih interpretacijah različnih veščin in znanj. Pod njegovim vodenjem študent razvija veščine, potrebne za opravljanje določenega dela, spoznava delovno okolje in se uči poklicnega vedenja.

Ker je praktično usposabljanje del študijskega programa, je za njegovo kakovostno izvajanje nenadomestljivo tesno sodelovanje med mentorji na fakulteti in mentorji v delovni organizaciji, saj gre za dopolnjevanje in prepletanje študentovih teoretičnih znanj s praktičnimi in ne nazadnje za vzgojo bodočega zaposlenega z vsemi njegovimi med študijem pridobljenimi spretnostmi in potenciali.

V nadaljevanju podrobneje predstavljamo praktično usposabljanje študentov zdravstvene nege v kliničnem okolju.

\section{PRAKTIČNO USPOSABLJANJE ŠTUDENTOV ZDRAVSTVENE NEGE}

Poklic medicinske sestre, za katerega se izobražujejo študenti zdravstvene nege, spada med regulirane poklice. Ker dostop do opravljanja te poklicne dejavnosti določajo zakon in drugi predpisi o posebnih poklicnih kvalifikacijah (Zakon o nacionalnih poklicnih kvalifikacijah, 2007), mora biti tudi program praktičnega usposabljanja usklajen z direktivo EU 2005/36 ES in z njo povezano slovensko zakonodajo. Tako so v Smernicah za praktično usposabljanje na Univerzi v Ljubljani (Kristl idr., 2007) zapisani cilji praktičnega usposabljanja za regulirane poklice, usklajenost z direktivo EU pa omogoča članicam vzajemno priznavanje dokazil o formalnih kvalifikacijah na podlagi minimalnih pogojev usposobljenosti ter s tem 
prost pretok delovne sile (prav tam). Ker imajo strokovna področja specifične zahteve glede praktičnega usposabljanja in tudi glede delovnih organizacij, kjer se praksa študentov lahko izvaja, Govekar-Okoliš (2011) postavlja v ospredje potrebo po dobrih in strokovno usposobljenih mentorjih tako na fakultetah kot $\mathrm{v}$ delovnih organizacijah.

Načelo usmerjenega vodenja in nadzora praktičnega usposabljanja je pomemben in že utečen del izobraževalnega procesa oziroma profesionalnega razvoja zdravstvenih delavcev. Gre za metodološko posredovanje potrebnih spretnosti, znanja in izkušenj za opravljanje neke delovne naloge, ki vsebuje tri komponente, in sicer vodenje, usmerjanje in prikazovanje. Pri tem želimo poudariti vzgojo za poklic in pridobivanje poklicnih spretnosti, veščin in znanj, zato lahko cilje usposabljanja tudi v zdravstveni negi opredelimo kot oblikovanje osebnosti, spreminjanje vedenja z osvajanjem poklicnih spretnosti in strokovno usposobljenost. Noben od omenjenih ciljev ni dosegljiv hitro in neposredno, temveč terja svoj čas, vložek energije, pomoč, sodelovanje in povezovanje med fakulteto in delovnim okoljem, kjer poteka praktično usposabljanje. Študent v konkretnem delovnem okolju ob pomoči mentorja in drugih sodelavcev povezuje teorijo s prakso, s čimer $\mathrm{v}$ ospredje stopa vzgojna komponenta. Vedenjska komponenta se izrazi prek celostnega spreminjanja vedenja, ko študent $\mathrm{z}$ učenjem teži k novim znanjem in obvladovanju novih delovnih postopkov. Tretji cilj pa pomeni strokovno usposobljenost za poklic, ki ga lahko utemeljimo z dejstvom, da mora biti zaposleni kvalificiran za svoje delo.

Omenjeni cilji so na področju zdravstvene nege zapisani v opredelitvi del in nalog zdravstvenega tehnika in medicinske sestre. Nekatere od teh ciljev najdemo tudi v Kodeksu etike medicinskih sester in zdravstvenih tehnikov (2005, str. 2-4), ki je temeljni dokument o etični drži ter spodbuda in vodilo pri delu v praksi zdravstvene nege.

Praktično usposabljanje na področju zdravstvene nege se po zakonu izvaja v zdravstveni ustanovi, ki ima status učnega zavoda. ${ }^{1}$ Delovno skupnost na področju zdravstvene nege sestavljajo različni zdravstveni zavodi, v katerih poteka praktično usposabljanje bodočih zdravstvenih delavcev različnih profilov. Na področju zdravstvene nege svoja poklicna dela in naloge opravljajo tehniki zdravstvene nege ${ }^{2}$ in medicinske sestre. ${ }^{3}$ Kot smo že zapisali, sodi njihov poklic med regulirane poklice.

1 Vsi zavodi, v katerih se izvaja praktično usposabljanje za regulirane poklice, imajo status učnega zavoda, saj morajo izpolnjevati pogoje, ki jih določa Pravilnik o pogojih, ki jih mora izpolnjevati zavod za izvajanje praktičnega pouka dijakov zdravstvenih šol in študentov visokošolskih zavodov za podelitev naziva učni zavod (2005, str. 10874).

2 Tehnik zdravstvene nege je oseba, ki je končala srednješolski strokovni program in je usposobljena za vrsto strokovnih del v okviru zdravstvene nege zdravih in bolnih v vseh življenjskih obdobjih in okoljih. Tehnik zdravstvene nege je član negovalnega tima in je po navodilu medicinske sestre izvajalec postopkov in posegov v procesu zdravstvene nege (Poklicne aktivnosti in kompetence v zdravstveni in babiški negi, 2008, str. 8). Po Zakonu o zdravstveni dejavnosti (2005, str. 1934) mora za samostojno opravljanje zdravstvene nege opraviti pripravništvo $\mathrm{v}$ trajanju šestih mesecev in strokovni izpit.

3 Medicinska sestra je opravila najmanj 12-letno splošno in/ali strokovno izobraževanje in končala visoko strokovno izobraževanje s področja zdravstvene nege ter ji je ustrezen organ podelil pravico za samostojno izvajanje $\mathrm{v}$ zdravstveni dejavnosti. V okviru svojih kompetenc je usposobljena za zadovoljevanje potreb po 
Po direktivi EU zajema usposabljanje medicinskih sester za splošno zdravstveno nego vsaj tri leta študija ali 4600 ur teoretičnega in kliničnega usposabljanja, pri čemer trajanje teoretičnega usposabljanja pomeni vsaj tretjino, trajanje kliničnega usposabljanja pa vsaj polovico minimalnega trajanja usposabljanja. Teoretični pouk je treba ovrednotiti in uskladiti s kliničnim poukom, tako da se lahko znanje in spretnosti pridobijo na ustrezen način. Pri kliničnem usposabljanju se medicinske sestre v skupini in v neposrednem stiku z zdravim ali bolnim posameznikom učijo organizirati, pripravljati in dajati zdravila ter oceniti zahtevano celovito zdravstveno nego na podlagi pridobljenega znanja in veščin. Medicinska sestra se nauči ne le delati v skupini, temveč tudi voditi skupino in organizirati celovito zdravstveno nego, vključno z zdravstvenim izobraževanjem posameznikov in manjših skupin v zdravstveni ustanovi (Kristl idr., 2007).

Iz zapisanih smernic torej lahko povzamemo, da je praktično usposabljanje pomemben del študijskega programa zdravstvene nege, časovno in organizacijsko pa pomeni velik izziv za učni zavod, kjer se usposabljanje študentov izvaja. To seveda od učnega zavoda terja ustrezno pripravo, organiziranje, pa tudi načrtno izbiro usposobljenih posameznikov, ki bodo prevzeli mentorstvo študentom na klinični praksi ter njihovo usposabljanje, ob podpori delovne organizacije in fakultete, izpeljali kakovostno in učinkovito. Praktično usposabljanje se izvaja na različnih oddelkih učnih zavodov po strokovnem področju v skladu s predmetnikom. Po opravljenem usposabljanju na enem oddelku študent začne usposabljanje na drugem oddelku, pri čemer zamenja tudi mentorja v delovnem okolju. Mentorji v delovnem okolju so sicer vnaprej določeni, glavni pogoj za izbiro pa je izkazan interes za delo s študenti ter odgovorno in predano delo v poklicnem okolju. Večinoma so to mentorji z dolgoletnimi izkušnjami, ni pa to pravilo, zlasti kadar gre za kadrovsko podhranjen oddelek. Usposabljanje mentorjev lahko poteka v okviru seminarjev in je pogosto odločitev posameznika in odvisno od njegove motivacije za izboljšanje dela s študenti.

Termin klinična praksa (oziroma usposabljanje) in njeno vodenje ter nadzor opisuje proces profesionalnega razvoja in učenja, ki omogoča študentu razvijati znanje, veščine, kompetence, odnos in odgovornost do prakse zdravstvene nege, ki zagotavlja varnost pacienta ter premišljene poteze in odločitve v kompleksnem kliničnem okolju (Ramšak Pajk, 2007). Klinično okolje je specifično učno okolje, ker omogoča izvajanje individualne oblike učenja ob pacientu, pri delu s svojci pacienta in ob delu s sodelavci. Nega ob pacientu se izvaja na human način, vključena je nesebična humana interakcija, tako da se pacient ob tem ne počuti ogroženega. Ni vljudno niti etično, če učimo študenta ob pacientu, ki s tem ni bil seznanjen ali se s tem predhodno ni strinjal.

Mentorji v kliničnem okolju se zavedajo svoje delovne situacije, zato morajo poznati obstoječe možnosti in biti pripravljeni, da jih izkoristijo na primeren način. Učne in poučevalne interakcije niso vedno oblikovane formalno ali idealno. Narava dela zahteva timski

zdravstveni negi in oskrbi, za zdravstveno vzgojo in izobraževanje, za organizacijo dela in razvojno raziskovalno dejavnost (Podoba medicinske sestre, 2003, str. 5). Medicinska sestra je članica širšega zdravstvenega tima, v katerem sodeluje pri načrtovanju in izvajanju celotne zdravstvene oskrbe pacienta (Poklicne aktivnosti in kompetence v zdravstveni in babiški negi, 2008, str. 8). 
pristop in tesno sodelovanje med vsemi sodelavci $\mathrm{v}$ negovalnem pa tudi širšem zdravstvenem timu. V medosebni odnos s študenti tako v okolju prakse vstopajo tudi drugi sodelavci v timu in prinašajo nove poglede, vedenja in spoznanja. Spodbudno učno okolje povečuje pripravljenost študenta na učenje, saj so po teoriji samoodločanja za razvoj notranje motivacije nujni trije pogoji - podpora kompetentnosti, avtonomiji in socialni pripadnosti (Ivančič, Mohorčič Špolar in Radovan, 2010). Vloga mentorja pri oblikovanju takega okolja je ključna, pa tudi pri izkoriščanju prednosti, možnosti in raznolikih priložnosti, ki jih ponuja delovno okolje za učenje, rast in razvoj študenta. Mentor namreč v kliničnem okolju deluje na dobro poznanem terenu, pozna paciente, sodelavce in druge člane zdravstvenega tima, ve, kje se kaj nahaja, pozna dnevno delovno rutino na oddelku, razume specifičen jezik in odnose med osebjem ter pozna dokumentacijo.

Študent pa se znajde v tujem okolju, zato potrebuje čas, da vsaj približno spozna novo delovno situacijo in procese v njej. Sposobnost posameznikovega prilagajanja ima tako pri praktičnem usposabljanju veliko vlogo. Študenti se v tem odzivajo zelo različno; nekateri želijo več in so bolj aktivni, drugi so manj motivirani in slabše izkoriščajo priložnosti za učenje. Razlike med njimi se kažejo tudi v nivoju in kakovosti predhodnega teoretičnega znanja. In ne nazadnje imajo študenti različne predhodne izkušnje, tudi tiste, ki so jih pridobili na praktičnih usposabljanjih $\mathrm{v}$ drugih učnih zavodih in okoljih. Vse to vpliva na njihove predstave, pričakovanja in cilje, ki jih oblikujejo, preden začnejo novo usposabljanje v kliničnem okolju.

Dober mentor bo opisane okoliščine sprejel kot izziv in s svojim ravnanjem študenta vključeval v izvajanje postopkov, ga spodbujal in mu izkazal zaupanje. V kliničnem okolju sprejema in igra vlogo učitelja, pomočnika, vodnika, svetovalca, ki daje podporo študentu, ga usmerja, motivira in išče nove priložnosti za učenje. Študent pod njegovim vodenjem in usmerjanjem razvije ustrezne kompetence, ki mu bodo omogočale učinkovito, neodvisno in odgovorno delo v njegovi stroki. $\mathrm{V}$ ta sodelovalni odnos oba, mentor in študent, prinašata svoje znanje, izkušnje, način razmišljanja in učenja ter svoje poglede in pričakovanja do drugega $v$ odnosu. Pogledi in pričakovanja mentorjev in študentov na usposabljanju v kliničnem okolju so bili eno od področij našega raziskovanja v izbranem učnem zavodu in nekaj naših ugotovitev predstavljamo v nadaljevanju.

\section{METODOLOGIJA}

Raziskavo, ki je obravnavala področje mentorstva na praktičnem usposabljanju študentov zdravstvene nege, smo opravili v izbranem učnem zavodu, kjer študenti opravljajo prakso. V vzorec smo vključili 194 medicinskih sester mentorjev, ${ }^{4}$ zaposlenih v delovnem okolju učnega zavoda, in 158 študentov 2. in 3. letnika študijske smeri zdravstvena nega na usposabljanju v izbranem učnem zavodu. Oblikovali smo raziskovalna vprašanja, vezana posebej na mentorje in posebej na študente. Za obe ciljni skupini smo pripravili vprašalnika, v katerih je bil delež vsebinsko identičnih vprašanj. Vprašalnike smo po

4 Za lažje razumevanje bomo v nadaljevanju uporabljali moški spol. 
predhodni napovedi razdelili obema skupinama; mentorjem smo vprašalnike razdelili na posameznih kliničnih oddelkih in jih prosili, naj izpolnjene vrnejo na dogovorjeno mesto. Študentom smo vprašalnike razdelili na koncu skupnih sestankov in jim dali potreben čas, da so lahko odgovorili na vprašanja in vrnili izpolnjene ankete. Dobljene rezultate smo obdelali na ravni deskriptivne statistike in z neeksperimentalno kavzalno metodo pojasnili vzročne zveze med raziskovanimi spremenljivkami. V raziskavi so nas med drugim zanimala medsebojna pričakovanja vključenih v mentorski odnos in njihov pogled na usposabljanje v kliničnem okolju, pri čemer smo želeli odgovoriti na naslednja raziskovalna vprašanja:

- Kakšna so medsebojna pričakovanja mentorjev in študentov v zdravstveni negi?

- Ali se ocena glede aktivnosti študentov na praktičnem usposabljanju med mentorji in študenti razlikuje?

- $\quad$ Ali so oblike mentorjevega dela s študenti usklajene z željami študentov?

- Kakšni so pogledi na kompetence uspešnih študentov med mentorji in študenti?

- Kako na mentorjeve naloge pri delu s študenti gledajo mentorji in kako študenti?

\section{REZULTATI IN INTERPRETACIJA}

Raziskava nam je razkrila nekatere posebnosti na področju praktičnega usposabljanja študentov zdravstvene nege v izbranem zavodu. Primerjava in analiza dobljenih odgovorov obeh ciljnih skupin odkriva različnost v njihovih medsebojnih pričakovanjih. V Tabeli 1 so prikazani odgovori mentorjev. Ugotavljamo, da med mentorji prevladuje odgovor, da od študentov pričakujejo več aktivnosti in samoiniciative (37,5 odstotka), vendar ne bistveno. Le nekaj manjše število vprašanih mentorjev od študentov pričakuje večji interes za delo in skoraj enako pogosto (30,4 odstotka) anketirani mentorji pričakujejo od študentov, da pred začetkom vaj ponovijo teoretične vsebine s področja, s katerim se bodo ukvarjali na vajah. Sklepamo, da jih skromno znanje teorije in nepripravljenost študentov na praktično usposabljanje ovirata pri vodenju in mentoriranju, ki ga zato ne morejo izpeljati, kot so načrtovali. Določene teoretične vsebine so namreč ključne za razumevanje študentov pri delu v kliničnem okolju in s tem za učinkovitost njihovega usposabljanja.

Tabela 1: Pričakovanja mentorjev

\begin{tabular}{|l|r|c|}
\hline Mentorjeva pričakovanja & Število & $\%$ \\
\hline 1 večji interes za delo & 62 & 32,1 \\
\hline 2 več aktivnosti, samoiniciative & 73 & 37,5 \\
\hline 3 boljša predhodna pripravlienost na vaje oziroma prakso & 59 & 30,4 \\
\hline Skupaj & 194 & 100,0 \\
\hline
\end{tabular}

Podobno vprašanje smo postavili tudi študentom; ti so odgovarjali, kaj na usposabljanju v praksi pričakujejo od mentorja. Njihovi odgovori so zbrani v Tabeli 2. 
Tabela 2: Pričakovanja študentov

\begin{tabular}{|l|c|c|}
\hline Študentova pričakovanja & Število & $\%$ \\
\hline 1 pomoč pri pridobivanju in utrjevanju praktičnih spretnosti & 59 & 37,4 \\
\hline 2 pomoč pri povezovanju pridobljenega teoretičnega znanja s prakso & 38 & 24,0 \\
\hline 3 da me navaja na odgovorno delo v timu in igra vlogo pozitivnega modela & 22 & 13,9 \\
\hline $\begin{array}{l}4 \text { da me spodbuja k osebnemu profesionalnemu razvoju in navaja na } \\
\text { vseživljenjsko učenje in izobraževanje }\end{array}$ & 37 & 23,5 \\
\hline 5 drugo & 2 & 1,2 \\
\hline Skupaj & 158 & 100,0 \\
\hline
\end{tabular}

Kot je razvidno iz Tabele 2, študenti od mentorja večinoma pričakujejo, da jim pomaga pri pridobivanju in utrjevanju praktičnih spretnosti. Približno enak je delež študentov, ki pričakujejo od mentorja pomoč pri povezovanju teoretičnega znanja s praktičnim, in tistih, ki pričakujejo predvsem spodbujanje k osebnemu profesionalnemu razvoju in navajanje na vseživljenjsko učenje. Najmanjši delež študentov pa od mentorja pričakuje vlogo pozitivnega modela in navajanje na odgovorno delo v timu.

Če povzamemo medsebojna pričakovanja anketiranih v obeh ciljnih skupinah, lahko sklepamo, da mentorji od študentov najpogosteje pričakujejo več samoiniciative in aktivnosti, študenti pa od mentorja, da jim pomaga pri pridobivanju in utrjevanju praktičnih spretnosti.

Iniciativa in aktivnost študenta v okolju prakse pozitivno vplivata na uspešnost in učinkovitost usposabljanja; pravzaprav je aktivnost njegov smisel. Zato smo raziskovanje poglobili z vprašanjem o tem, kaj menijo mentorji o stopnji aktivnosti študentov na usposabljanju in kako svojo aktivnost ocenjujejo študenti. Odgovore mentorjev sicer nakazuje že Tabela 1, podrobneje pa odgovore obeh ciljnih skupin prikazuje Tabela 3.

Tabela 3: Doživljanje aktivnosti študentov med mentorji in študenti

\begin{tabular}{|l|l|r|r|r|}
\hline \multicolumn{2}{|c|}{ Aktivnosti študentov } & 1 Mentorii & 2 Študenti & Skupai \\
\hline \multirow{3}{*}{1 nikoli } & Število & 3 & 16 & 19 \\
\cline { 2 - 5 } & $\%$ & 1,5 & 10,1 & 5,4 \\
\hline \multirow{3}{*}{2 včasih } & Število & 171 & 77 & 248 \\
\cline { 2 - 5 } & $\%$ & 88,2 & 48,8 & 70,5 \\
\hline \multirow{3}{*}{3 vedno } & Število & 20 & 65 & 85 \\
\cline { 2 - 5 } & $\%$ & 10,3 & 41,1 & 24,1 \\
\hline \multirow{3}{*}{ Skupai } & Število & 194 & 158 & 352 \\
\cline { 2 - 5 } & $\%$ & 100,0 & 100,0 & 100,0 \\
\hline
\end{tabular}


Primerjava odgovorov mentorjev in študentov kaže na razlike v doživljanju aktivnosti študentov med ciljnima skupinama. Mnenje, da so študenti na vajah vedno dovolj aktivni, je med študenti večinsko, enako mnenje pa izraža le malo mentorjev. Večina mentorjev ocenjuje, da študenti svojo aktivnost pokažejo le občasno, tako pa meni tudi slaba polovica študentov. Odgovor »nikoli« se presenetljivo pogosteje pojavlja v skupini vprašanih študentov, kar nakazuje na določeno mero samokritičnosti; ta odgovor je izbralo zanemarljivo malo vprašanih mentorjev. Lahko torej povzamemo, da so pogledi na aktivnost študenta na kliničnih vajah oziroma praktičnem usposabljanju v izbranem zavodu med vprašanima skupinama precej različni. Menimo, da je ta ocena zelo pomembna pri načrtovanju sprememb v praktičnem usposabljanju študentov v smislu dvigovanja kakovosti.

V nadaljevanju smo ugotavljali, kako so želje študentov glede oblik dela usklajene z oblikami, ki jih mentorji na praktičnem usposabljanju najpogosteje uporabljajo. Študente smo v anketi vprašali, katerih oblik dela si želijo na praktičnem usposabljanju. Njihovi odgovori so prikazani v Tabeli 4.

Tabela 4: Katerim oblikam dela dajejo prednost študenti?

\begin{tabular}{|l|r|c|}
\hline Oblike dela & Število & \multicolumn{1}{c|}{$\%$} \\
\hline 1 svetovanje & 86 & 47,5 \\
\hline 2 konzultacija & 28 & 15,5 \\
\hline 3 inštrukcija & 32 & 17,7 \\
\hline 4 supervizija & 35 & 19,3 \\
\hline Skupaj & 181 & 100,0 \\
\hline
\end{tabular}

Ugotavljamo, da študenti najpogosteje izražajo željo po tem, da bi jim mentorji več svetovali. Naslednja najpogosteje zaželena oblika dela z mentorjem je supervizija (s to obliko so študenti seznanjeni že v okviru predmeta na fakulteti), želje po inštrukcijah in konzultacijah pa so med študenti redkejše. Ob tej interpretaciji se nam porajajo določene dileme glede razumevanja pojma »konzultacija« med študenti in morebitno njegovo poistovetenje s pojmom »svetovanje«. Na tej točki se kaže slabost našega inštrumenta, saj med študenti nismo predhodno preverili razumevanja posameznih pojmov, ki opisujejo oblike dela s študenti.

Uporabljene oblike dela na praktičnem usposabljanju smo v raziskavi preverili tudi med mentorji. Njihove navedbe o pogostosti uporabe posameznih oblik dela smo rangirali in razvrstili v Tabeli 5. V odgovorih pomeni 4 najvišjo oceno - »zelo pogosto« in 1 najnižjo $-\gg$ nikoli $\ll$. 
Tabela 5: Katere oblike dela mentorii najpogosteje uporabljajo?

\begin{tabular}{|l|c|}
\hline Oblika dela s študenti glede na pogostost uporabe & Povprečje \\
\hline svetovanje & 2,86 \\
\hline konzultacija & 2,29 \\
\hline inštrukcije & 2,27 \\
\hline supervizija & 1,98 \\
\hline drugo & 1,94 \\
\hline
\end{tabular}

Odgovori, zbrani v tabeli, kažejo, da mentorji pri delu s študenti na praktičnem usposabljanju najpogosteje svetujejo, medtem ko so konzultacije in inštrukcije po pogostosti precej izenačene. Najredkeje mentorji uporabijo supervizijo. Glede razumevanja posameznih pojmov skoraj ne gre dvomiti, da si jih mentorji ustrezno razlagajo. Gre namreč za vsebine, s katerimi se mentorji seznanijo v okviru svojega strokovnega izpopolnjevanja na seminarjih s pedagoško tematiko. Dopuščamo možnost, da se sicer pri posamezniku lahko pojavi morebitna napačna interpretacija ali razumevanje določenega pojma, vendar to na končni rezultat bistveno ne vpliva.

Če torej povzamemo naše ugotovitve, lahko rečemo, da si tako študenti kot mentorji želijo oziroma delajo isto. Študenti poleg mentorstva dajejo prednost svetovanju, to pa je tudi oblika dela, ki jo njihovi mentorji najpogosteje uporabljajo. Zato lahko sklepamo, da se njihovi interesi v tem polju srečajo.

Poleg identifikacije interesov glede oblik dela na praktičnem usposabljanju nas je v raziskavi zanimalo tudi, kakšni so pogledi anketiranih v obeh ciljnih skupinah na kompetence, ki naj jih razvije oziroma ki jih potrebuje uspešen študent. Tabela 6 prikazuje, kako so mentorji in študenti razvrstili posamezne kompetence uspešnega študenta po pomembnosti.

Primerjava odgovorov med skupinama kaže na to, da mentorji in študenti prvim štirim kompetencam $\mathrm{v}$ tabeli pripisujejo podoben pomen. Nekoliko prednosti $\mathrm{v}$ primerjavi z mentorji pa dajejo študenti zadnjima dvema kompetencama; prva se nanaša na znanja in možnosti strokovnega izobraževanja in profesionalnega razvoja, druga pa zadeva poznavanje konkretnih situacij in vlog $\mathrm{v}$ instituciji ter vrednotenje lastnih kompetenc. Zadnja kompetenca je očitno študentom za oceno o lastni uspešnosti pomembnejša kot mentorjem in kaže na potrebo študenta po gotovosti, ki jo povezuje s poznavanjem različnih vlog in svojega položaja v instituciji. Vendar je v delovnem okolju, kjer se ti študenti usposabljajo, največkrat težko predvideti vse dogodke, včasih sta potrebna hitro prilagajanje in iznajdljivost študenta. To so dogodki, pri katerih se od mladega človeka ne pričakuje, da jim bo v celoti in vedno kos. Menimo, da tukaj nastajajo razlike med študenti in mentorji pri oceni pomena te kompetence.

Kljub nekaterim razlikam med skupinama pri ocenjevanju pomena posameznih kompetenc pa je končna razvrstitev kompetenc uspešnih študentov med skupinama zelo 
Tabela 6: Razvrščanje posameznih kompetenc uspešnih študentov med mentorii in študenti

\begin{tabular}{|l|c|c|c|c|}
\hline \multirow{2}{*}{ Kompetence uspešnih študentov } & \multicolumn{2}{|c|}{1 Mentorii } & \multicolumn{2}{|c|}{2 Študenti } \\
\cline { 2 - 5 } & $\mathrm{N}$ & Povprečje & $\mathrm{N}$ & Povprečje \\
\hline $\begin{array}{l}\text { Zna sodelovati z zaposlenimi v instituciji, } \\
\text { obvlada komunikacijo, ima občutek za } \\
\text { delo z ljudmi, s pacienti. }\end{array}$ & 194 & 3,75 & 158 & 3,92 \\
\hline $\begin{array}{l}\text { Zna povezovati teoretično znanje s praktič- } \\
\text { nim in z izkušnjami. }\end{array}$ & 194 & 3,68 & 158 & 3,66 \\
\hline $\begin{array}{l}\text { Zna kritično opazovati in ovrednotiti svoj } \\
\text { proces praktičnega usposabljanja. }\end{array}$ & 194 & 3,54 & 158 & 3,53 \\
\hline $\begin{array}{l}\text { Ima primeren odnos do sredstev, ki jih } \\
\text { uporablja pri svojem delu. }\end{array}$ & 194 & 3,49 & 158 & 3,51 \\
\hline $\begin{array}{l}\text { Ima znanja o pomenu in možnostih oseb- } \\
\text { nega strokovnega izobraževanja in lastne- } \\
\text { ga profesionalnega razvoja. }\end{array}$ & 194 & 3,11 & 158 & 3,27 \\
\hline $\begin{array}{l}\text { Pozna konkretne situacije in različne vloge } \\
\text { znotraj institucije, zna ovrednotiti svoje } \\
\text { kompetence. }\end{array}$ & 194 & 2,89 & 158 & 3,26 \\
\hline
\end{tabular}

podobna. Sklepamo lahko, da imajo študenti in mentorji podobne poglede na to, katere lastnosti so tiste, ki posameznega študenta določajo in opisujejo kot uspešnega. Njihove poglede na prednostne mentorjeve naloge pri pridobivanju in razvijanju teh kompetenc pa odstira naslednje vprašanje. Anketirane v obeh ciljnih skupinah smo vprašali, kako vidijo prednostne naloge mentorja pri vodenju študenta na praktičnem usposabljanju. Odgovore smo zbrali v Tabeli 7.

Tabela 7: Razvrščanje mentorjevih nalog po prednosti med mentorji in študenti

\begin{tabular}{|c|c|c|c|c|}
\hline \multirow{2}{*}{\multicolumn{2}{|c|}{ Mentorjeve naloge }} & \multicolumn{2}{|c|}{ KDO - mentorii, študenti } & \multirow{3}{*}{$\begin{array}{r}\text { Skupaj } \\
74\end{array}$} \\
\hline & & \multirow{2}{*}{$\frac{1 \text { Mentorii }}{18}$} & \multirow{2}{*}{$\frac{2 \text { Študenti }}{56}$} & \\
\hline 1 pridobivanje in utrjevanje praktič- & Število & & & \\
\hline nih spretnosti & $\%$ & 9,3 & 36,5 & 21,0 \\
\hline \multirow{2}{*}{$\begin{array}{l}2 \text { povezovanje pridobljenega teore- } \\
\text { tičnega znanja s prakso }\end{array}$} & Število & 104 & 39 & 143 \\
\hline & $\%$ & 53,6 & 24,8 & 40,6 \\
\hline \multirow{2}{*}{$\begin{array}{l}3 \text { navajanje na odgovorno delo v } \\
\text { timu in vloga pozitivnega modela }\end{array}$} & Število & 20 & 22 & 42 \\
\hline & $\%$ & 10,3 & 13,9 & 11,9 \\
\hline \multirow{2}{*}{$\begin{array}{l}4 \text { spodbujanje k osebnemu profesi- } \\
\text { onalnemu razvoju, izobraževanju }\end{array}$} & Število & 52 & 39 & 91 \\
\hline & $\%$ & 26,8 & 24,8 & 25,9 \\
\hline \multirow{2}{*}{ Skupaj } & Število & 194 & 158 & 352 \\
\hline & $\%$ & 100,0 & 100,0 & 100,0 \\
\hline
\end{tabular}


Kot ugotavljamo, večina mentorjev meni, da je njihova naloga pomagati študentu pri povezovanju teoretičnega znanja s praktičnim, medtem ko študenti v večini menijo, da jim bo mentor pomagal predvsem pri pridobivanju in utrjevanju praktičnih znanj. Rezultati se ujemajo s predhodnimi odgovori mentorjev, ko so ti izrazili željo po tem, da bi študenti ponovili teoretične vsebine pred začetkom vaj in na vaje prišli pripravljeni. Očitno je, da želja izhaja prav iz tega, kako mentorji vidijo svojo nalogo pri mentoriranju oziroma kje vidijo namen svojega dela s študentom. Zagotovo študent, ki je svoje teoretično znanje pred začetkom kliničnih vaj osvežil, na praktičnem usposabljanju laže sodeluje, hitreje poveže smisel posameznega postopka, ne nazadnje s svojo pripravo pokaže tudi večji interes oziroma motiviranost za vaje, kar lahko posledično vodi v njegovo večjo aktivnost. Koliko študentov se predhodno pripravi na praktično usposabljanje, je bilo tudi eno od vprašanj v anketi za študente in njihovi odgovori so prikazani v Tabeli 8.

Tabela 8: Predhodna priprava študentov na klinične vaje

\begin{tabular}{|l|r|r|}
\hline $\begin{array}{l}\text { Na prakso se pripravim nekaj dni prej, } \\
\text { tako da osvežim teoretične vsebine. }\end{array}$ & Število & $\%$ \\
\hline 1 ne velja & 47 & 29,7 \\
\hline 2 delno velja & 105 & 66,5 \\
\hline 3 popolnoma velja & 6 & 3,8 \\
\hline Skupai & 158 & 100,0 \\
\hline
\end{tabular}

Kot kažejo odgovori v tabeli, se zanemarljivo majhno število anketiranih študentov ( 3,8 odstotka) na vaje pripravi vedno, slaba tretjina (29,7 odstotka) pa nikoli. Večina anketiranih študentov (66,5 odstotka) je odgovorila, da zgoraj zapisana trditev zanje velja le delno. Spomnimo, da so v raziskavi anketirani študenti v veliki večini izrazili željo tudi po drugih oblikah povezovanja z mentorjem (svetovanje, supervizija, inštrukcije, konzultacija), kar pa seveda terja določeno aktivnost na strani študenta, ki vključuje tudi predhodno pripravo na praktično usposabljanje.

Glede na zbrane in analizirane podatke lahko zaključimo, da med mentorji in študenti zdravstvene nege obstajajo določene razlike $\mathrm{v}$ pogledih in pričakovanjih, ki jih imajo na praktičnem usposabljanju v kliničnem okolju drug do drugega. Različne so tudi njihove interpretacije lastnih nalog in vlog v okviru usposabljanja.

\section{UGOTOVITVE RAZISKAVE}

Značilnosti mentorstva na področju zdravstvene nege v kliničnem okolju med drugim določajo medsebojna pričakovanja študentov in mentorjev, udeleženih v mentorskem odnosu. Ta so, kot kaže naša raziskava v izbranem zavodu, precej različna. Mentorji dojemajo praktično usposabljanje kot priložnost za študenta, da teoretična znanja, pridobljena na fakulteti, poveže s prakso. Od študentov zato pričakujejo, da se na vaje predhodno pripravijo in ponovijo teoretične vsebine, ki jih bodo potrebovali za lažje razumevanje dela 
v okolju prakse. Njihova pričakovanja so obenem usmerjena v študentovo samoiniciativo in aktivnost, pričakujejo pa tudi večji interes študentov za delo. Študenti na drugi strani vidijo v praktičnem usposabljanju priložnost za pridobivanje in utrjevanje praktičnih spretnosti, pa tudi možnost povezovanja teoretičnega znanja s prakso. Tem pričakovanjem je brez predhodne priprave študentov na usposabljanje v kliničnem okolju v smislu osvežitve teoretičnih vsebin teže zadostiti. Prav to ugotavljamo v naši raziskavi, namreč da se dejansko večina študentov na usposabljanje ne pripravi, s tem pa se že na začetku prakse v kliničnem okolju postavijo v nekakšno pasivno vlogo, kjer predvsem veliko pričakujejo od mentorja. Sicer so v raziskavi (Kermavnar, 2015) svojo nepripravljenost največkrat opravičili s preobremenjenostjo s študijskimi obveznostmi in posledično s pomanjkanjem časa. Pogosto pa so navedli tudi neusklajenost urnika praktičnega usposabljanja s predavanji, ko so imeli praktično usposabljanje razpisano pred predavanji, torej preden so sploh poslušali teoretične vsebine, ki jih sicer na usposabljanju, če naj povežejo teorijo s prakso, nujno potrebujejo. Vsekakor to ni dobra popotnica za začetek praktičnega usposabljanja. Tu je naloga na strani fakultete, da uskladi urnik predavanj z urnikom usposabljanja $\mathrm{v}$ praksi, kot to predvideva študijski program. Odgovornost pa je tudi na strani študenta, ki mora razumeti namen in smisel praktičnega usposabljanja kot del svoje študijske obveznosti in se nanj ustrezno pripraviti. Tako bo tudi sam od usposabljanja imel več koristi, več informacij, več spoznanj, več novopridobljenega znanja, ki ga bo laže povezal s starim. Pridobivanje in utrjevanje praktičnih znanj namreč predvideva in od posameznika zahteva aktivnost. To pa je ena od prepoznanih »kritik« na strani mentorjev, ki v svojih odgovorih opozarjajo, da študenti na praktičnem usposabljanju pokažejo premalo iniciative in so premalo aktivni. Mnenja na strani študentov so drugačna. Sebe namreč v večini prepoznavajo kot aktivne posameznike, ki na praktičnem usposabljanju pokažejo zadostno stopnjo iniciative. Pa vendar je v odgovorih študentov, zajetih v vzorec, zaznati določeno indiferentnost. V izjavah, ki v raziskavi (prav tam) opredeljujejo in natančneje kažejo njihovo motiviranost, aktivnost in vključenost na praktičnem usposabljanju, so prevladovali nevtralni odgovori in torej ni bilo izrazito pozitivnih odgovorov, ki bi podprli njihove trditve in ocene o lastni aktivnosti.

Čeravno se stališča anketiranih na področju medsebojnih pričakovanj med ciljnima skupinama precej razlikujejo, pa se glede oblik dela želje enih in izbira drugih na praktičnem usposabljanju povsem uskladijo. Študenti si od oblik dela na usposabljanju najbolj želijo mentorjevo svetovanje, to pa je oblika, ki jo mentorji pri mentorstvu študentov tudi najpogosteje uporabljajo. Tudi v zvezi s kompetencami uspešnega študenta ugotavljamo podobno. Tako mentorji kot študenti kompetence, ki jih študent potrebuje za uspešno doseganje ciljev na praktičnem usposabljanju, po pomembnosti vrednotijo zelo podobno. Nekoliko več pomena kot mentorji študenti sicer pripisujejo naslednjima kompetencama: znanju o pomenu in možnostih profesionalnega razvoja ter spretnosti v poznavanju lastne vloge v instituciji in konkretnih situacij v kliničnem okolju. Ta ocena se ujema s študentovo potrebo po varnosti v delovnem okolju in procesih $\mathrm{v}$ njem, ki jih ne pozna dovolj in kjer se ne čuti suverenega. 
Ob zapisanih interpretacijah rezultatov menimo, da se v izbranem učnem zavodu izkazuje potreba po pogovoru med mentorjem in študenti ob začetku praktičnega usposabljanja. V njem bi lahko obe strani izrazili svoja pričakovanja in želje v času usposabljanja, jih poskušale uskladiti in jim slediti, obenem pa bi odpravili morebitne napačne predstave $o$ izvajanju usposabljanja. Prepričani smo, da bi bilo zadovoljstvo obeh strani, tako študentov kot mentorjev, pri sodelovanju večje, pa tudi pogledi vseh na aktivnost posameznih študentov na praktičnem usposabljanju bi bili precej bolj podobni.

\section{ZAKLJUČEK IN PREDLOGI}

Mentorstvo študentom zdravstvene nege opredeljujejo določene posebnosti, ki izhajajo iz narave poklica, na katerega se študenti na praktičnem usposabljanju pripravljajo, in iz začetnih pričakovanj mentorjev in študentov, ki se vključujejo v mentorski odnos. Posebnost bodočega poklica narekuje predvsem delo $\mathrm{z}$ bolnimi in pomoči potrebnimi posamezniki ter skrb za sočloveka. Načela, kot so humanost, moralnost, etičnost in strokovnost, so podlaga za vsako delo na področju zdravstvene nege, zato jih mora študent, ki prihaja na praktično usposabljanje, poznati, razumeti, sprejeti in udejanjiti pri svojem delu v kliničnem okolju. Mentorjeva naloga je, da študentu pri tem pomaga in ga usmerja, da koristno poveže svoja teoretična znanja $z$ delom $v$ praksi in tako nadgradi nabor svojih vedenj in znanj. Da bi se izognili neusklajenosti $\mathrm{v}$ pričakovanjih in predstavah $\mathrm{v}$ zvezi z usposabljanjem $\mathrm{v}$ praksi, pa menimo, da bi bilo na začetku praktičnega usposabljanja smiselno opraviti pogovor $\mathrm{s}$ študenti. Mentor naj ta pogovor opravi v sklopu uvodnega sestanka, pri čemer naj pojasni namen usposabljanja, njegove vsebine in cilje. To narekuje tudi potrebo po povezanosti kliničnega mentorja z mentorjem v izobraževalni instituciji, kar zagotavlja ustrezno informiranost o vsebinah in potrebnih predhodnih znanjih študentov. Študent naj ima na pogovoru možnost izraziti svoje želje in interese, pa tudi morebitne zadržke, strahove in dileme. Obenem mentor posreduje svoja pričakovanja študentu, ga seznani z njegovimi obveznostmi in odgovornostjo pri delu v kliničnem okolju. Skupaj oblikujeta individualni načrt praktičnega usposabljanja, ki upošteva vsebine in sklepe, za katere sta se dogovorila skupaj. S takšnim načinom priprave na usposabljanje študenta v praksi močno povečamo učinkovitost in uspešnost njegovega usposabljanja; s tem ko zadostimo potrebam študenta, obenem zadostimo tudi ciljem in potrebam mentorja ter tudi vseh drugih, odgovornih za izobraževanje in usposabljanje študentov, ki bodo v prihodnosti vključeni v skrb za zdravje naše družbe.

\section{LITERATURA}

Govekar-Okoliš, M. (2011). Characteristics of mentors in the practical training of students. V J. B. Holen, A. L. Phillips (ur.), Studies in education from diverse contexts (str. 59-69). Grand Forks: College of education and human development, University of North Dakota.

Govekar-Okoliš, M. (2012). The importance of the practical training of students at the University of Ljubljana in Slovenia. V J. Veteška (ur.), Perspektivy učení a vzdělávání v evropském kontextu = Prospects of learning and education in European context (str. 243-250). Praga: Universita Jana Amose Komenského Praha. 
Govekar-Okoliš, M. (2013). Practical training of students and the realisation of lifelong learning. V M. Radovan, M. Kościelniak (ur.), Lifelong learning today : new areas, contexts, practices (str. 83-95). Krakov: Jagiellonian University Press.

Govekar-Okoliš, M. in Gruden, U. (2011). Ugotovitve in spoznanja z izobraževanja mentorjev za praktično usposabljanje študentov. Andragoška spoznanja, 17(1), 62-73.

Ivančič, A., Mohorčič Špolar, V. in Radovan, M. (2010). Formalno izobraževanje odraslih v Sloveniji: percepcije in izkušnje udeležencev. Ljubljana: Andragoški center Slovenije.

Kermavnar, N. (2015). Mentorstvo kot andragoška oblika dela na primeru praktičnega usposabljanja študentov (Doktorska disertacija). Filozofska fakulteta, Ljubljana.

Kodeks etike medicinskih sester in zdravstvenih tehnikov Slovenije. (2005). Pridobljeno s http://www. uradni-list.si/content?=97901.

Kristl, J., Juriševič, M., Šoukal-Ribičič, M., Pucelj, J., Vrtačnik, M., Trošt, Z. ... Kolenc, M. (2007). Smernice za praktično usposabljanje na Univerzi v Ljubljani. Ljubljana: Univerza v Ljubljani.

Merila za akreditacijo visokošolskih zavodov in študijskih programov (2004). Uradni list RS, št. 101/2004.

Merila za kreditno vrednotenje študijskih programov po ECTS (2004). Uradni list RS, št. 124/2004.

Podoba medicinske sestre (2003). Pridobljeno s http://www.zbornica-zveza.si/sites/default/files/ doc_attachments/podoba_medicinske_sestre/pdf.

Poklicne aktivnosti in kompetence $v$ zdravstveni in babiški negi (2008). Pridobljeno s http://www.zbornica-zveza.si/sites/default/files/doc_attachments/poklicne_aktivnosti_in_kompetence08.pdf.

Pravilnik o pogojih, ki jih mora izpolnjevati zavod za izvajanje praktičnega pouka dijakov zdravstvenih šol in študentov visokošolskih zavodov za podelitev naziva učni zavod (2005). Uradni list RS, št. 103/2005.

Ramšak Pajk, J. (2007). Pomen mentorstva in praktičnega usposabljanja v izobraževanju za zdravstveno nego. Obzornik zdravstvene nege, 41(2-3), 71-75.

Zakon o nacionalnih poklicnih kvalifikacijah (2007). Uradni list RS, št. 1/2007.

Zakon o visokem šolstvu (2006). Uradni list RS, št. 119/2006.

Zakon o zdravstveni dejavnosti (2005). Uradni list RS, št. 23/2005.

Zakon o zdravstveni dejavnosti (2008). Uradni list $R S$, št.15/2008, št. 23/2008. 